\title{
Directing Corporate Entrepreneurship Strategy in the Public Sector to Public Value: Antecedents, Components, and Outcomes
}

\section{Claudine Kearney \& Timo Meynhardt}

To cite this article: Claudine Kearney \& Timo Meynhardt (2016) Directing Corporate Entrepreneurship Strategy in the Public Sector to Public Value: Antecedents, Components, and Outcomes, International Public Management Journal, 19:4, 543-572, DOI: 10.1080/10967494.2016.1160013

To link to this article: $\mathrm{http}: / / d x . d o i . o r g / 10.1080 / 10967494.2016 .1160013$

Accepted author version posted online: 16

Mar 2016.

Published online: 16 Mar 2016

Submit your article to this journal 주

山ll Article views: 192

View related articles ־

View Crossmark data $\asymp$ 
International

Public

Management

Journal

\title{
DIRECTING CORPORATE ENTREPRENEURSHIP STRATEGY IN THE PUBLIC SECTOR TO PUBLIC VALUE: ANTECEDENTS, COMPONENTS, AND OUTCOMES
}

\author{
CLAUDINE KEARNEY \\ UNIVERSITY COLLEGE DUBLIN \\ TIMO MEYNHARDT \\ UNIVERSITY OF ST. GALLEN
}

\begin{abstract}
Over the last three decades, organizations worldwide have used corporate entrepreneurship (CE) as a means of building new competencies, revitalizing operations, achieving renewal, and/or creating value for stakeholders. However, little is understood about factors triggering corporate entrepreneurship strategy (CES) within organizations not driven by profit motives. The purpose of this article is to conceptualize CES in the public sector in order to synthesize, integrate, and link the key concepts within the CE domain, thereby creating new public value and generating new economic activity for the benefit of multiple stakeholders. The public sector CES model includes (1) the antecedents of public sector CES (external environmental conditions that generate entrepreneurial activity); (2) the key components of CES (entrepreneurial strategic vision, organizational conditions that support entrepreneurial processes and behavior, entrepreneurial orientation (EO) that reflects the overall level of such processes and behavior, and individual levels of entrepreneurial behavior); and (3) outcomes of CES within the public sector (organizational outcomes resulting from entrepreneurial actions, including the development of venturing and renewal that, in turn, leads to enhanced public value). We discuss how our model contributes to the CE literature, followed by implications for scholars and practice and future research directions.
\end{abstract}

\section{INTRODUCTION}

The interface between two key areas of research offers promising new insights into the management of public sector organizations. The first of these involves the nature 
and roles of strategic thinking and strategic direction in affecting the performance of public sector entities (Andrews et al. 2005; 2011; Hendrick 2003). The second addresses entrepreneurship and innovation within the public sector, an area of growing interest, especially as public organizations confront increasingly challenging environments (Bartlett and Dibben 2002; Currie et al. 2008; Walker, Damanpour, and Devece 2011). An important topic linking these two areas of research is corporate entrepreneurship strategy (CES), defined as "a vision-directed, organization-wide reliance on entrepreneurial behavior that purposefully and continuously rejuvenates the organization and shapes the scope of its operations through the recognition and exploitation of entrepreneurial opportunity" (Ireland, Covin, and Kuratko 2009, 21).

In the last three decades, public sector literature has given increased attention to entrepreneurship (e.g., Doig and Hargrove 1990; Kearney, Hisrich, and Roche 2010; Morris and Jones 1999), corporate entrepreneurship (CE) (e.g., Kearney, Hisrich, and Roche 2008), strategy, internal organizational characteristics, and performance (e.g., Andrews et al. 2007; 2009; 2011), and public value (e.g., Bryson Crosby, and Bloomberg 2014; 2015; Meynhardt 2009; 2011; 2015; Moore 1995; 2013; Stoker 2006). However, our knowledge of how external environmental and internal organizational characteristics govern the contribution of $\mathrm{CE}$ to performance is sparsely researched within public settings (Kearney, Hisrich, and Roche 2010). Currie and Proctor (2005) suggest that environmental turbulence and resource scarcity combine to create among public managers a growing recognition that public value performance is influenced by entrepreneurial actions at multiple levels in the organization. Yet, how public sector managers can develop and implement CES to create public value is not well understood. Within a public sector context, CES would seem extremely important because public managers are increasingly expected to prescribe strategies for overcoming external threats and internal constraints, while at the same time improving performance (Meier and O'Toole 2009) and enhancing public value (Bryson, Crosby, and Bloomberg 2014; Moore 1995; 2013).

Entrepreneurship research and its related topics have led scholars to advance numerous variants, such as international entrepreneurship, policy entrepreneurship, not-for-profit entrepreneurship, social entrepreneurship, and public sector entrepreneurship. This suggests subtle yet important differences in entrepreneurship across these diverse contexts. Private sector management principles have been introduced into the public sector over the past few decades (e.g., Kearney, Hisrich, and Roche 2010; Meynhardt and Diefenbach 2012; Morris and Jones 1999; Morris, Webb, and Franklin 2011). Adapting CES to the public sector allows researchers to capture the specific strategies and forms of entrepreneurship within the public sector context. Public sector organizations represent a particular context characterized by important differences from CES in private sector organizations. Public sector organizations are formed with the purpose of fulfilling a societal need (Boris and Steuerle 2006) and thus create public value (Moore 1995). Public sector organizations face unprecedented demands from a society that grows more complex and interdependent by the day (Morris and Jones 1999). This sector includes organizations serving important functions; for example, education, health, 
religion, human services, and arts and culture (Salamon 1992). It also includes organizations with public features such as many nonprofits and third-sector organizations, for hospitals, trade associations, professional societies, and museums (Nutt and Backoff 1995). In essence, public sector entrepreneurship is manifested in a variety of activities, including changing the organizational environment or rules of the game, establishing new public organizations, creating and managing new public resources, and taking advantage of spillovers from private action for the wider good (Klein et al. 2010).

This article aims to open up avenues of exploration for public sector CES development and practice. Of particular interest in this study is our understanding of the differences in the manifestation of CES in a private and public sector context and the factors underlying those differences. CES within the public sector is a distinct organizational strategy through which public sector organizations adopt a strategic approach that allows them to successfully determine how and when to initiate entrepreneurial activities. In this context, the objective is to demonstrate the congruence among the core components of CES and the effect of these on CE and public value within the public sector. Similar to the private sector (Ireland, Covin, and Kuratko 2009; Kreiser et al. 2011), the model proposes that internal congruence among the core components of CES results in higher levels of CE and, in turn, enhances organizational performance in terms of public value. The core value of external congruence among environmental and CES components is that it further enhances the level of congruence among the internal components of CES within the public sector in light of the external environment. Boyne (2006) asserts that the lack of fit with the external environment is a key reason for public sector strategies to fail. Herein, the public value approach provides a means to address this issue, because it fosters the outside-in perspective of an administration. The ability of CES to drive CE to enhance public value is likely contingent upon the organization's ability to relate to its external environment.

The objective of this article is to contribute to this field of inquiry and present a model of CES in the public sector. The specific purpose of our work is to outline a model depicting (1) the external environmental antecedents of CES; (2) the most salient components of CES; and (3) the organizational outcomes resulting from the adaptation of CES. We develop propositions to consider how to direct CES in the public sector. In doing so, we seek to unmask the complex role of CES as a factor in these relationships. Further, we aim to depict how CES could be conceptualized and provide a valuable opportunity for scholarly examination to advance our knowledge about CES and its application to the public sector.

\section{A MODEL OF PUBLIC SECTOR CORPORATE ENTREPRENEURSHIP STRATEGY}

As depicted in Figure 1, a model of public sector CES as a distinct organizational strategy is developed which synthesizes previous theoretical and empirical research. Inspired by the work of Hornsby et al. (2009), Ireland, Covin, and Kuratko (2009), 


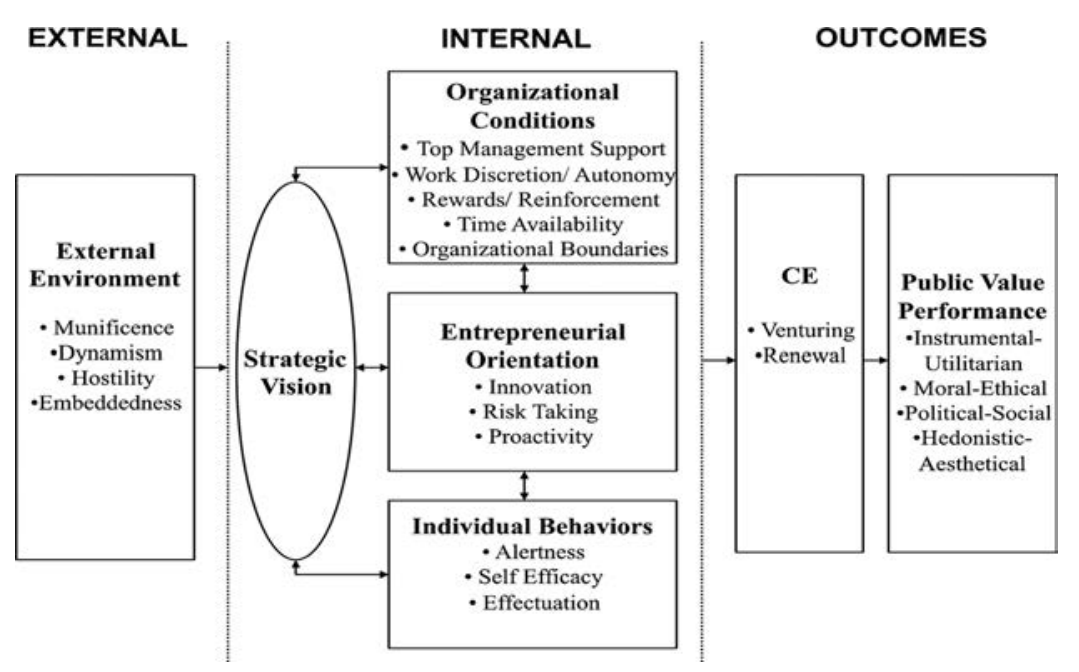

Figure 1. A model of public sector corporate entrepreneurship strategy.

and Kreiser et al. (2011), our research suggests that CES in the public sector is significantly influenced by the public sector's unique external environment, which, in turn, shapes key internal components and outcomes. The proposed model suggests that public sector CES is manifested through the presence of four components: an entrepreneurial strategic vision as the essence of an administrations idea of how to serve society, organizational conditions that support entrepreneurial processes and behavior, entrepreneurial orientation (EO) that reflects the overall level of such processes and behavior, and individual levels of entrepreneurial behavior. A public sector organization's sustained effort to develop CES depends on individual members undertaking entrepreneurial activities and being supported by top management, which, in turn, will support the allocation of fundamental organizational conditions. This model implies that congruence among the core components of CES has a profound effect on CE and, in turn, enhances performance as measured by public value. In addition, the core value of congruence among external environmental conditions and CES factors further enhances the level of congruence among the internal components of CES within the public sector. By enhancing congruence among the internal components of CES, the organization is in a position to positively respond to corporate entrepreneurial opportunities as they emerge, thus enhancing public value performance.

For the following constructs, we need to understand the differences in the manifestation of CES between the private and public sector and the factors underlying these differences. To do this, we synthesize previous research, highlight the meaning underlying each construct, and discuss the general differences in the public sector context. In doing so, we provide the basis for a new approach for capturing the manifestation of CES in the public sector context. 


\section{THE ANTECEDENTS}

\section{External Environment Antecedents}

The external environment has been frequently recognized as having a strong influence on the existence and effectiveness of entrepreneurial activity (Covin and Slevin 1991). Conditions that can precipitate the perceived need for entrepreneurial action include levels of environmental hostility, dynamism, and heterogeneity (Zahra 1991). Further examples of specific environmental factors (e.g., Kuratko, Hornsby, and Goldsby 2004; Lumpkin and Dess 1996) have been identified, but these studies have predominately involved private sector organizations. Within the public sector, entrepreneurship has also been approached as a means of capitalizing on external opportunities while achieving effectiveness, flexibility, and adaptability in dealing with a turbulent environment (Moon 1999).

There are increasingly common environmental conditions that can precipitate the perceived need for a corporate strategy (Ireland, Covin, and Kuratko 2009). CES is recognized as a fundamental strategic approach when congruent with certain environmental conditions, which may include characteristics such as munificence (e.g., Dess and Beard 1984; Kearney, Hisrich, and Roche 2010; Zahra 1993b), dynamism (e.g., Antoncic and Hisrich 2001; Covin and Slevin 1991; Zahra 1993b), hostility (e.g., Covin and Slevin 1991; Ireland, Covin, and Kuratko 2009; Zahra and Covin 1995; Zahra 1991; 1993b) and embeddedness (e.g., Battilana 2006; Bruton, Ahlstrom and Li 2010; Granovetter 1985).

We believe that an entrepreneurial strategic vision is an appropriate response to four key external environmental conditions: munificence, dynamism, hostility, and embeddedness. Other environmental conditions could be antecedents to public sector entrepreneurial strategic vision, given the theoretical and empirical support for their significance. However, we focus on these four conditions as the principal external transformational triggers that can lead to the emergence of an entrepreneurial strategic vision in the public sector.

Environmental munificence is the scarcity or abundance of critical resources that are provided by the environment and required by an organization (Dess and Beard 1984). Environmental munificence reflects the richness of opportunities for CE in an industry (Aldrich 1979). The more munificent the environment, the greater the expected internal rate of return on CE (Simsek, Veiga, and Lubatkin 2007). From the organization level of analysis, the degree of munificence is directly related to an organization's ability to acquire resources from the environment and may influence organizational performance (Bruno and Tyebjee 1982). Public sector organizations need to adapt to increased environmental munificence to be alert to new opportunities and strengthen their position in an economy that, for example, has rapidly deteriorating public finances and significant levels of unemployment (Kearney, Hisrich, and Roche 2010).

Dynamism refers to the extent to which environments that organizations operate are subject to unpredictable and rapid change and, thus, to high levels of uncertainty (Dess and Beard 1984; Miller 2007). Dynamism also indicates uncertainty that 
inhibits a manager's ability to predict future events as well as their impact on the organization (Khandwalla 1977). A dynamic environment in the public sector can be the "authorizing environment" and/or a "task environment." Nutt and Backoff (1992) suggest that the "authorizing environment" and the interdependent actors can be considered the actual market of the public organization, the interests of which it must strive to satisfy in the act of strategic management. In the "task environment," public sector managers must be prepared to adapt and reposition their organizations in addition to simply ensuring their continuity (Moore 1995). They must work hard at the task of defining publicly valuable enterprises and also achieve that value. Both "authorizing" and "task" environments demand and facilitate change, and require performance on different dimensions of value or on different tasks. In the public sector, environmental uncertainty has been identified as a prerequisite for entrepreneurship (Boyett 1997). Highly dynamic environments are more likely to engender high levels of activation among entrepreneurs than less dynamic environments (Baron and Tang 2011). Public sector organizations need to adapt to a highly dynamic environment (Kearney, Hisrich, and Roche 2007) that, in turn, responds to global challenges and brings opportunities and confidence to an economy and society as a whole.

Environmental hostility tends to create threats for the organization and stimulates the pursuit of CE (Zahra 1991). Hendrick (2003) argues that the concept of environmental hostility must be defined more broadly in a public sector context, to include not just resources, economic conditions, and external organizations (e.g., other government bodies) but, most importantly, political and social conditions that determine objectives and constrain the ability to meet those objectives. Hostility is often considered the obverse of munificence; it is indicative of scarcity and intensity of competition for environmental resources (Zahra and Covin 1995). Hence, the relative amounts of munificence and/or hostility in the environment are key drivers of strategy (Walker 2008).

Embeddedness refers to the ties an organization and its members form with its environment (Granovetter 1985). Being in close contact with the diversity of stakeholders, partners, citizens, and the wider public could help to identify needs and opportunities for new services, interaction patterns with the public, and/or new organizational forms to better fulfill the legal mandate. In this sense, entrepreneurship in the public sector often involves the creation of "a whole new system of meaning that ties the functioning of disparate sets of institutions together" (DiMaggio 1988, 14). Meynhardt and Diefenbach (2012) found that the perceived "multitude of expectations" in the environment and the degree to which public managers are involved in the local environment ("localism") were strong antecedents for EO. Similarly, Mack, Green, and Vedlitz (2008) recognized the importance of focusing on the local environment. Such involvement within networks and within the social context may be regarded as social capital, which Floyd and Wooldridge (1997) identify as an important antecedent for organizational members to act entrepreneurially.

Public sector organizations are a separate form of organization that serves the needs of society. Like the private sector, they must adapt to external environmental conditions. Yet, these environmental factors differ between sectors, leading to 
different conditions for CE (Sadler 2000). Despite sector specifics, for any organization it is fundamental to recognize and adapt to external factors, and sense potential opportunities and conflicts. In response to one or more environmental conditions, entrepreneurial organizations manifest CES through four components: entrepreneurial strategic vision, entrepreneurial organizational environment, organizationallevel EO, and individual-level entrepreneurial behavior.

First, it is fundamental that top managers develop and support an entrepreneurial strategic vision. Top managers are recognized as the "purveyors of vision" (Heller 1999) and shapers of corporate purpose (Bartlett and Ghoshal 1997). In the public sector, the notion of vision is bounded by the legislative framework and policymaking, which requires sense making and interpretation to find ways to better and more efficiently fulfill the mandate (Meynhardt and Metelmann 2009). Moore (1995) translated relevant challenges for the public sector by deploying the notion of "upward attention"; i.e., a constant search for legitimacy and authority from the political environment. Second, the value of an entrepreneurial organizational environment is frequently enhanced in munificent (e.g., Kearney, Hisrich, and Roche 2010), dynamic (e.g., Antoncic and Hisrich 2001), hostile (e.g., Ireland, Covin, and Kuratko 2009), and highly embedded environments (e.g., Ahlstrom and Li 2010), with the purpose of creating congruence between the internal and external environment (e.g., Morris, Kuratko, and Covin 2011). Third, theoretical support indicates that EO represents an viable approach in conjunction with high levels of munificence (e.g., Caruana, Ewing, and Ramaseshan 2002), high levels of dynamism (e.g., Khandwalla 1987), high levels of hostility (e.g., Khandwalla 1977; Zahra and Covin 1995), and high levels of embeddedness (Meynhardt and Diefenbach 2012). Fourth, for entrepreneurship to be achieved at the organizational level, it requires individuals that are alert to opportunities, have a strong self belief, and use logic to recognize and exploit viable opportunities. These characteristics are manifested through alertness, self-efficacy, and effectuation. Moore (1995) offered a metaphor of an explorer to frame EO in the public sector, and argued that such an image "is closer (but by no means identical) to the image society has of managers in the private sector: In this view public managers are seen as explorers who, with others, seek to discover, define and produce public value" (Moore 1995, 20). These explanations are formalized in the following hypothesis:

H1: In the public sector, the level of environmental (a) munificence, (b) dynamism, (c) hostility, and (d) embeddedness will be positively associated with the four components of public sector CES (strategic vision, organizational conditions, EO, and individual behaviors).

\section{COMPONENTS OF CORPORATE ENTREPRENEURSHIP STRATEGY}

CES encompasses the various initiatives related to corporate venturing and strategic entrepreneurship (Morris, Kuratko, and Covin 2011). Organizations with 
an entrepreneurial strategic vision demonstrate that entrepreneurial activity is the core-defining attribute (Ireland, Covin, and Kuratko 2009). CES in the public sector requires a strategic vision that demonstrates a strong organizational commitment to entrepreneurial values, philosophies, and beliefs. For the public sector to develop an entrepreneurial strategic vision and deal with economic challenges, this vision must be adapted to external environmental conditions (Kearney, Hisrich, and Roche 2010). Within a public sector context, CES would seem a particularly relevant strategic approach. Public managers are increasingly expected to prescribe strategies for overcoming external threats and internal constraints, while at the same time improving performance (Meier and O'Toole 2009). With the exception of Bryson's (2011) work, there is little guidance regarding the appropriate strategic means of dealing with such threats and constraints. Andrews et al. (2007) highlight efforts for public organizations to achieve greater adaptability in addressing developments in the environment; notably, through their approaches to strategy, structure, and management of internal resources. Furthermore, entrepreneurship is a key dimension of Miles and Snow's strategy typology; i.e., prospectors, analyzers, defenders, and reactors (Wang 2008). All four types of firms must deal with the "entrepreneurial problem" (Miles and Snow 1978). Prospectors approach the environment more proactively; defenders attempt to create a stable domain; analyzers prosper by purposely being more innovative; and reactors are the "residual" type of behavior in that firms are forced into this response mode only when they are unable to pursue one of the first three strategies (Miles and Snow 1978).

An entrepreneurial strategic vision is a process that allows top managers to develop a plan for the future of the organization. Strategy in the public sector is not about achieving competitive advantage or attracting profitable customers, but instead represents a means for improving public services (Boyne and Gould-Williams 2003). The growing emphasis on strategy has been linked to increased managerialism in the public sector, uncertainties around funding levels and sources, and the need for more transparency in aims, outputs, and outcomes (Llewellyn and Tappin 2003). Public sector managers are challenged by bureaucratic procedures in the development of their strategic vision. Furthermore, public sector top management needs to engage in shaping the organization to achieve its strategic vision by ensuring it has appropriate systems in place to generate success in the various entrepreneurial activities undertaken (Kearney, Hisrich, and Roche 2010). The strategic vision of top managers towards entrepreneurship is the foundation of CES. Doig and Hargrove (1990) show how government executives' ability to set goals, generate support inside and outside the bureaucracy, and implement innovative ideas, even at risk to their own careers, can have a significant impact on their organizations and on society. In developing this conceptual model, it is argued that CES in the public sector is built upon an entrepreneurial strategic vision, organizational conditions that support such vision, EO that captures the degree to which an organization is entrepreneurial, and individual entrepreneurial behaviors as exhibited throughout the organization. While there are significant similarities to many of the private sector components and dimensions, fundamental differences in the nature of public sector organizations raise questions regarding what approaches are applied and how they are implemented (Nutt and Backoff 1993). 


\section{Organizational Conditions Support Corporate Entrepreneurship Strategy}

As research on CES has developed, numerous researchers (e.g., Antoncic and Hisrich 2001; Burgelman 1983; Covin and Slevin 1991; Guth and Ginsberg 1990; Hornsby, Kuratko, and Zahra 2002; Hornsby et al. 2009) have recognized the importance of the internal organizational conditions to promote and support performance. Since public sector organizations exist to create public value rather than achieve profits (Moore 1995), strategic approaches in the public sector usually focus on ways of improving performance (Andrews et al. 2011). CES is reflected in the willingness of an organization to foster and maintain organizational conditions that are conducive to entrepreneurship (e.g., Covin and Slevin 1991; Hornsby et al. 2009). Research on internal factors conducive to facilitating CES is more limited, and generally relies on private sector studies. Recently, some well-established variables from the private sector have been tested in the public sector (Kearney and Morris 2015; Meynhardt and Diefenbach 2012). Research has identified and supported specific organizational antecedents of managers' entrepreneurial behavior to include: top management support, work discretion/autonomy, rewards/reinforcement, time availability, and organizational boundaries (Goodale et al. 2011; Hornsby, Kuratko, and Zahra 2002; Hornsby et al. 2009; Kuratko, Montagno, and Hornsby 1990). Furthermore, this structure has been used to establish organizational antecedents in the public sector (Meynhardt and Diefenbach 2012) with similar results. Ireland, Kuratko, and Morris (2006a; 2006b) have argued that the Corporate Entrepreneurship Assessment Instrument (CEAI) survey instrument, designed to measure each of the five aforementioned organizational antecedents to $\mathrm{CE}$, provides a sound basis for managers to effectively assess, manage, facilitate, and improve $\mathrm{CE}$ activities. The CEAI scales have been well established through subsequent research (e.g., Goodale et al. 2011; Holt, Rutherford, and Clohessy 2007; Hornsby, Holt, and Kuratko 2008; Hornsby et al. 2009; Kuratko, Hornsby, and Bishop 2005; Rutherford and Holt 2007). Thus, theory and empirical results pertaining to the CEAI scales support the existence of five stable organizational antecedents of managers' entrepreneurial behavior, as described in the following.

Top management support is the extent to which one perceives that top managers support, facilitate, and promote entrepreneurial behavior, including the championing of innovative ideas and providing the resources people require to take entrepreneurial actions (e.g., Antoncic and Hisrich 2001; Goodale et al. 2011; Hornsby, Kuratko, and Zahra 2002; Hornsby et al. 2009), and has been found to have a positive relationship with an organization's entrepreneurial outcomes (e.g., Antoncic and Hisrich 2001; Hisrich and Kearney 2011; Kuratko, Ireland, and Hornsby 2001; Morris, Kuratko, and Covin 2011). Similar to the private sector, public sector managers are more likely to behave entrepreneurially when they perceive support for such behavior (Meynhardt and Diefenbach 2012). Top management support is especially important when innovative entrepreneurial projects are to be integrated into the regular organization (Westrup 2012). Therefore, releasing creative energy in pursuit of the public interest requires top management support of entrepreneurship in the public domain. 
Work discretion/autonomy is the extent to which one perceives that the organization tolerates failure, provides decision-making latitude and freedom from excessive oversight, and delegates authority and responsibility to lower-level managers and workers (Hornsby, Kuratko, and Zahra 2002; Hornsby et al. 2009). Public sector managers are more likely to behave entrepreneurially when they perceive discretion in their work (Meynhardt and Diefenbach 2012). Entrepreneurial outcomes frequently arise from those with discretion over how to perform their work as well as by those encouraged to engage in experimentation (e.g., Kuratko, Ireland, and Hornsby 2001). Public sector leaders "earn autonomy" and consequently may enjoy more discretion to enact entrepreneurial in cases where considered "excellent" against centrally prescribed performance indicators (Currie et al. 2008).

Rewards and reinforcement are the extent to which one perceives that the organization uses systems that reward based on entrepreneurial activity and success (Hornsby, Kuratko, and Zahra 2002; Hornsby et al. 2009). Reward systems that encourage risk taking and innovation have been shown to have a strong effect on individuals' tendencies to behave entrepreneurially (Block and Ornati 1987; Sathe 1989; Sykes 1986). Rewarding employees for success is not just the tangible financial returns, but includes recognition, feedback, and meaningful work (Hisrich and Kearney 2011). Introducing performance-based remuneration in the public sector can be detrimental to performance, as it crowds out intrinsic motivation (Weibel, Rost, and Osterloh 2010). For entrepreneurial activity to develop in the public sector, there is a need for positive rewards that recognize the contribution of individuals and groups within the organization (Kearney, Hisrich, and Roche 2009).

Time availability for managers is an important resource for generating entrepreneurial outcomes (e.g., Slevin and Covin 1997; Stopford and Baden-Fuller 1994). Managers are expected to invest "slack" time in the most prominent tasks, given their roles and responsibilities (Hornsby et al. 2009). The availability of free time can enable potential corporate entrepreneurs to consider opportunities for innovation that may be precluded by their required work schedules (Shepherd, McMullen, and Jennings 2007). Allowing appropriate time and resources to enable entrepreneurship in the public sector can create value for citizens and stakeholders by utilizing acquired resources to exploit social opportunities.

Flexible organizational boundaries can be useful in promoting entrepreneurial activity because they enhance the flow of information between the external environment and the organization as well as between departments/divisions within the organization (Miller, Fern, and Cardinal 2007). Organizational boundaries can ensure the productive use of innovation-enabling resources (Goodale et al. 2011). Greater flexibility and adaptability are necessary for entrepreneurial activity to flourish in the public sector as high levels of rigidity and red tape are in conflict with entrepreneurial development (Kearney, Hisrich, and Roche 2009). Interestingly, Sadler (2000) finds that CE in the public sector can occur even when structures are hierarchical (a result of the need to foster some forms of traditional bureaucracy to ensure accountability).

These conditions have been theorized in the literature to support CE in a variety of private sector organizations (e.g., Goodale et al. 2011; Hornsby, Kuratko, and Zahra 
2002; Hornsby et al. 2009), as well as being recognized as being important in future public sector research (Kearney, Hisrich, and Roche 2007). Therefore, we hold that these five components - top management support, work discretion/autonomy, rewards and reinforcement, time availability, and flexible organizational boundaries - are an appropriate conceptualization of the entrepreneurial conditions of a public sector organization. With these observations in mind, we suggest the following hypothesis:

$\mathrm{H} 2$ : In the public sector, a clearly developed and communicated entrepreneurial strategic vision is positively associated with (a) top management support, (b) work discretion/ autonomy, (c) rewards/reinforcement, (d) time availability, and (e) flexible organizational boundaries.

\section{Entrepreneurial Orientation}

EO was conceptualized three decades ago and is a central component of entrepreneurship and strategy research. EO is an organization's strategic posture towards entrepreneurship that has become a fundamental construct of interest in CES research. Early research on EO has focused on three underlying dimensions: innovativeness, risk taking, and proactiveness (e.g., Covin and Slevin 1989; Miller 1983). There is an implicit assumption that EO is a behavioral orientation or posture that applies to any type of organization (Morris, Webb, and Franklin 2011). Recent developments in public sector management have recognized the need for public sector organizations to understand how EO can be achieved (Meynhardt and Diefenbach 2012). EO's dimensionality within the public and nonprofit sector can be expected to mirror its dimensionality in the private sector (Morris, Webb, and Franklin 2011). Yet differences between the public and private sector suggest modifications of the dimensions.

Previous studies have found a positive link between EO and performance among public sector organizations (e.g., Caruana, Ewing, and Ramaseshan 2002). Therefore, it is an appropriate indicator of the behavior-related element of CES in the public sector. However, the meaning of innovativeness, risk taking, and proactiveness is more complex and multifaceted in the public sector context. This necessitates a change in the definition of EO in order to capture unique aspects of this context. Using Covin and Slevin's (1989) definition, the EO concept is modified for the purpose of public sector as follows:

EO in a public sector organization is demonstrated by the extent to which the top managers are inclined to favor change and innovation for the organization (the innovation dimension), to take business-related risks (the risk taking dimension), and to take proactive strategic action (the proactiveness dimension) in order to achieve goals and objectives for the greater good of society at large.

In terms of the organization's posture, innovativeness is reflected in an organization's commitment to supporting new ideas, creativity, and experimentation in 
relation to the development of new products, services, and processes (Lumpkin and Dess 1996). Innovation in the public sector has gained an increased interest from scholars and practitioners (Borins 2014; Brown and Osborne 2013; Damanpour, Walker, and Avellaneda 2009; Hartley, Sørensen, and Torfing 2013; Osborne and Brown 2011; Walker 2014). There is a growing body of evidence regarding the influence of innovation on public sector performance (Walker, Damanpour, and Devece 2011). Public sector innovations seek to enhance social performance through reorganizations of cross-sector decision making, financing, and production systems (Moore and Hartley 2008). Furthermore, innovation can contribute to improve the quality of public services as well as enhance the problem-solving capacity of governmental organizations to manage societal challenges (Damanpour and Schneider 2009; Walker, Damanpour, and Devece 2011). The public sector organization's vision can lead it to pursue innovations that provide more effective benefits and to scale these benefits to a larger, more diverse market. Sanger and Levin $(1992,88)$ found that, "innovative public managers are entrepreneurial: they take risks ... with an opportunistic bias towards action and a conscious underestimating of bureaucratic and political obstacles their innovations face." There is general agreement that a well-performing public sector must rely on creativity and innovation to overcome problems (Vigoda 2002). Innovation is a fundamental part of the provision of effective public services (Osborne and Brown 2011). Borins (1998) found that opportunities for innovation in the public sector arise from circumstances peculiar to the public sector and that innovation is much less focused on commercial considerations than in the private sector. It is important to recognize these differences in order to develop entrepreneurship within the public sector and obtain the benefits that are generated by an effective entrepreneurial culture (Kearney, Hisrich, and Roche 2009). Borins's (2000) study of entrepreneurial public servants examined the origin of public sector innovations, the nature of the innovations, the factors leading to the approval and support of the innovations, and how public sector managers overcome obstacles to implementing the innovations. Such work suggests that entrepreneurial public innovators add public value by developing a clear vision, maintaining focus on social goals, proactively solving problems, and ethically overcoming obstacles, resulting in improved service and lower costs (Borins 2000).

Risk taking is the extent to which organizations and their managers are willing to commit significant resources to uncertain projects, where outcomes are unknown and there is risk of substantial loss (e.g., Lumpkin and Dess 1996; Wiklund and Shepherd 2003). Managers in private sector organizations are usually able to associate risk levels with prospective returns. However, the risk equation in public sector is more complex and difficult to quantify. Public sector managers are more risk sensitive (Kearney, Hisrich, and Roche 2010), taking calculated risks, while managing events that will promote positive outcomes (Morris and Jones 1999). The public sector needs to promote "prudent risk taking" and "experimenting" by providing room for failure, in order to pull public officials out of routines and encourage proactive action to solve problems (Dilulio, Garvey, and Kettl 1993, 76). However, the notion that public sector organizations tend to be more risk-averse than their private sector counterparts is challenged by Bozeman and Kingsley (1998), who tested this 
assumption in an empirical study and did not find evidence for higher risk aversion in the public sector. Public sector risk taking is reflected in investment decisions and strategic actions in the face of bureaucracy, uncertainty, and political obstacles.

Proactiveness is the extent to which an organization supports and facilitates the anticipatory development and implementation of innovations in advance of others, thereby enabling growth and enhanced performance (Morris, Webb, and Franklin 2011). "Proactiveness entails an action-orientation and an emphasis on anticipating and preventing public sector problems before they occur" (Morris and Jones 1999, 76). Public sector proactivity is action oriented, with perseverance for change and a focus on anticipating and overcoming potential obstacles that may inhibit the public sector (Kearney, Hisrich, and Roche 2007). This can focus on, for example, the process of change relative to stakeholders' expectations or being proactive in ways that can contribute to economic recovery and reform.

The manner in which a public sector organization exploits entrepreneurial opportunities is different from the private sector (for example, renewal and EO can be affected by political agendas or the "invisible hand" from the state). Furthermore, public agencies have a variety of stakeholders, each of whom place separate demands and constraints on managers (Kearney, Hisrich, and Roche 2010). At times of global complexity where there are significant economic challenges, public sector organizations need EO even more than their profit maximizing private sector counterparts in order to achieve long-term financial sustainability and stave off the complacency, rigidity, and stagnation that can go with organizational bureaucracy. In summary, we propose:

H3: In the public sector, a clearly developed entrepreneurial strategic vision is positively related to the probability that individuals and groups in an organization will demonstrate entrepreneurial behavior by (a) being more innovative; (b) taking risks necessary to exploit entrepreneurial opportunities; and (c) being proactive in search of opportunities.

\section{Individual Behaviors}

Entrepreneurial behavior continues to be seen as an important path to improved performance in all types of organizations (e.g., Lumpkin and Dess 1996). It can be manifested through many specific actions - (1) entrepreneurial alertness; (2) entrepreneurial self-efficacy; and (3) entrepreneurial effectuation — which are individual-level indicators of entrepreneurial behavior. These measures are grounded in individuallevel psychological and cognitive theories.

Kirzner (1973) was the first to use the term "alertness" to explain entrepreneurial opportunity recognition. Kirzner $(1997,72)$ refers to entrepreneurial alertness as "an attitude of receptiveness to available, but hitherto overlooked, opportunities." Building on Kirzner (1997), Shockley, Frank, and Stough (2002) specify that entrepreneurial alertness is crucially important for public sector entrepreneurship, but has been overlooked by existing theories that place too strong of a focus on rational calculation. 
Ray and Cardozo (1996) argued that any recognition of opportunity by a prospective entrepreneur is preceded by a state of heightened alertness to information. Personality characteristics and the environment interact to create conditions that foster higher entrepreneurial alertness (Gaglio and Taub 1992; Hisrich 1990; Sathe 1989). In order to exploit these opportunities, public sector entrepreneurs may demonstrate alertness to "policy windows," a concept introduced by Kingdon (1984), which represents an opportunity to push through or obtain support for a particular proposal. It is the ability to interpret political or market pointers to opportunities for taking direct ownership of available resources, or generating new business within a constrained environment, which distinguishes entrepreneurship in the public sector (Currie et al. 2008).

Self-efficacy relates to the general belief in one's ability to produce high levels of performance in tasks undertaken in life (Bandura 1977a; 1977b). Entrepreneurial self-efficacy refers to the strength of an individual's belief that he or she is capable of successfully performing the roles and tasks of an entrepreneur (Boyd and Vozikis 1994; Scherer et al. 1989). Individuals with high levels of self-efficacy tend to set challenging goals, persist toward the achievement of their goals, even under difficult and stressful circumstances, and recover quickly from failure, even in the face of conditions that would appear to be overwhelming to the average person (Bandura 1997). As a result, self-efficacy tends to increase motivation (e.g., Davidson and Eden 2000; Wright 2004; 2007), fueling high performance (Stajkovic and Luthans 1998). Research has found that working with employees to develop performance resources and strategies increases employee self-efficacy and job attendance in public sector organizations (Frayne and Latham 1987; Latham and Frayne 1989).

"Effectuation processes take a set of means as given and focus on selecting between possible effects that can be created with that set of means" (Sarasvathy 2001, 245). Effectuation argues that expert entrepreneurs use the logic of non-predictive control to transform means at hand into new outcomes that they themselves may not have initially envisaged (Ericsson 2006). The effectuation approach suggests that thinking and action proceed together in aiming to create one of several possible outcomes (Mitchell et al. 2007). Effectuation predetermines how much loss is viable and concentrates on experimenting with as many strategies as possible with the limited means available. Effectuation assumes that the future is unpredictable but entrepreneurs can control a value-creating part of it through the use of a given set of means available to them (Mitchell et al. 2007). Entrepreneurs can utilize the means at their disposal to influence their future without having to predict it (Sarasvathy 2001). In more complex environments where the future is more unpredictable and there are limited resources available, effectuation is an important process for public sector organizations.

Research has shown that there is an increased likelihood of an entrepreneurial opportunity being recognized among individuals with higher entrepreneurial alertness (Ardichvili, Cardozo, and Ray 2003), higher self-efficacy (Krueger and Dickson 1994), and effectuation (Mitchell et al. 2007). However, the pursuit of opportunities depends on how attractive they are to the individuals who recognized them first (Ireland, Covin, and Kuratko 2009). This link between individual and organizational goals, however, may extend beyond the boundaries of the organization in the public sector because of the congruence between the altruistic nature of 
public sector goals and the desire public sector employees have to do work that helps others and benefits society (Crewson 1997). If public sector employees perceive their own work as important to accomplishing goals that benefit society, they may strive harder to achieve their goals utilizing their alertness, self-efficacy and effectuation. This suggests the following hypothesis:

H4: In the public sector, a clearly developed and communicated entrepreneurial strategic vision is positively related to the probability that individuals will (a) develop an entrepreneurial alertness to opportunities; (b) have a strong degree of entrepreneurial self-efficacy; and (c) behave with logic and entrepreneurial effectuation.

\section{THE OUTCOMES}

\section{CES to Corporate Entrepreneurship}

Although researchers have proposed various definitions of CE, the literature distinguishes two core entrepreneurial activities in established organizations that center on either corporate venturing or strategic renewal (e.g., Guth and Ginsberg 1990; Verbeke, Chrisman, and Yuan 2007). Corporate venturing is concerned with the organization's creation of new business by expanding operations in new or existing markets (Zahra 1996). Strategic renewal encompasses a broad range of possibilities involving continuing incremental changes, discontinuous transformations and a range of precipitating circumstances, including but not limited to technological change (Agarwal and Helfat 2009), which can improve public sector performance (Kearney, Hisrich, and Roche 2010). Examples could include a repositioning strategy (e.g., a public hospital focusing on prevention rather than treatment), development of new business models (e.g., to guide postal service operations), resource acquisition and deployment strategies (e.g., a public housing authority leveraging relationships with businesses or non-profit entities), or innovation strategies that include streams of new products (e.g., for student learning in schools or purifying municipal water supplies), services (e.g., to recycle waste or ensure public safety), and processes (e.g., approaches enabling an unemployment agency to process more claims in less time or a fire department to more quickly contain a fire) (Kearney and Morris 2015).

$\mathrm{CE}$ in the public sector has been explored as a deliberate search for innovative change (Kearney, Hisrich, and Roche 2010; Linden 1990), the generation of new sources of revenue, the provision of enhanced services through the involvement of citizens (Bellone and Goerl 1992), and continuous innovation to enhance efficiency and effectiveness (Osborne and Gaebler 1992). The underlying drive for public sector entrepreneurship is to create value for citizens (Currie et al. 2008; Morris and Jones 1999) through corporate venturing and strategic renewal. Stoker $(2006,44)$ asserted that public value management involves "achieving public value that in turn involves greater effectiveness in tackling the problems that the public most cares about; and stretches from service delivery to system maintenance." CE has increasingly been recognized 
as one method to achieve high levels of organizational performance (Morris, Kuratko, and Covin 2011). Private organizations are mainly focused on shareholder value driven by profits, while public sector organizations are driven by progress in achieving social outcomes, a need to provide value to multiple stakeholders, and the need to generate sufficient revenues to maintain or enhance operational efficiency and effectiveness. While public sector organizations can emphasize certain commercial forms of entrepreneurship, the predominant emphasis is on serving the public interest and creating public value (Meynhardt 2009; 2011; Moore 1995; 2013).

One way to address venturing and strategic renewal in the public sector is Moore's (1995; 2013) "strategic triangle." Moore was particularly concerned with providing practical advice to public managers on how to use the assets that were entrusted to them in an entrepreneurial way. Thus, Moore's focus is primarily directed towards tactics and behaviors to foster venturing and renewal as a precondition to public value creation. In this context, public sector strategy must align three distinct but interdependent processes: (1) defining public value by clarifying and specifying public value outcomes in a particular context; (2) legitimatizing and authorizing action by creating an "authorizing environment" that builds a coalition of stakeholders from the public sector, the private sector, the community, and voluntary sector, whose support is necessary to sustain action; and (3) building operational capacity by harnessing and mobilizing operational resources both within and outside the organization to implement policy and achieve the desired public value outcomes (Benington and Moore 2011; Meynhardt 2009; Meynhardt and Bartholomes 2011). Those three processes are integral parts of corporate venturing and strategic renewal. They can be interpreted as one practical example of how to adapt them to the public sector.

To bring about venturing and renewal-i.e., to "play an active role in steering networks of deliberation and delivery and maintain the overall capacity of the system" (Stoker 2006, 44) — it takes individual behaviors and a consistent interplay between all internal components.

The following hypothesis is offered:

H5: In the public sector, congruence among four components of public sector CE (strategic vision, organizational conditions, EO, and individual behaviors) is positively associated with (a) corporate venturing and (b) strategic renewal.

\section{Corporate Entrepreneurship and Performance Outcomes}

A major factor separating public and private sector CE is defining and measuring the desirable outcome: performance. In the public sector, performance data are often missing and hard to collect and what constitutes good performance can be contested (Nutt 2005). This makes for a greater challenge for measuring performance within the public sector than in the private sector, where results include increased levels of financial performance (e.g., Antoncic and Hisrich 2001; Austin, Stevenson, and 
Wei-Skillern 2006; Zahra 1991; 1993a), creating new ventures or innovative project teams within established corporations (Hisrich and Peters 1986), new venture growth (Baum, Locke, and Smith 2001), product innovation (Jennings and Young 1990), enhanced levels of innovation (Burgelman 1983; Goodale et al. 2011), public welfare and social legitimacy (Pfeffer 1994), or simply personal satisfaction (Miner 1997).

The profit orientation in the private sector is not appropriate in the public sector because profitability is not its primary goal (Ramamurti 1986; Talbot 2010). Misguided entrepreneurship in the public sector, when public managers only try to optimize financial results, can be harmful to the public interest (Denhardt and Denhardt 2000). CE in the public sector identifies market opportunities within the political landscape, maximizes the entrepreneurial potential to enhance performance, and carries stakeholders in a way that permits risk as well as recognize the stewardship of public sector resources (Currie et al. 2008). It follows that the pursuit of CE in the public sector is driven by the desire to change, adapt, innovate, and tolerate risk at the institutional level (Forster, Graham, and Wanna 1996) and usually has both social and economic goals (Thompson and Doherty 2006). Public sector organizations are complex, facing a turbulent external environment with eroding tax bases, greater accountability and transparency, rapidly changing technology, and increasingly diverse stakeholders and clients to serve. CE can be a means to generating alternative revenues, improving internal processes, and developing innovative solutions to meet social and economic needs. As the public sector is not a profit-oriented organization, performance has to be understood as a multidimensional construct.

Moore (1995) argues that the creation of public value is the central activity of public managers, just as the creation of private value is at the core of private sector managers' action. Within the notion of value creation, the public sector performance can be equated "with initiating and reshaping public sector enterprises in ways that increase their value to the public in both the short and the long run" (Moore 1995, 10). Bryson (2010) defines strategic management within the public sector in terms of public value creation, stating that, "strategic management may be viewed as the appropriate and reasonable integration of strategic planning and implementation across an organization (or other entity) in an ongoing way to enhance the fulfillment of mission, meeting of mandates, continuous learning, and sustained creation of public value" (Bryson 2010, 256). Such a "public value" embraces both financial and non-financial measures (Meynhardt 2009).

To create public value, public managers must ensure that their work is of substantive value to the citizenry (Moore 1995) and make the correct decisions about the needs to be satisfied, the strategies to satisfy those needs, and the processes to produce and deliver services (Spano 2009). Public value theory suggests several dimensions to determine whether public value has been created. Moore's (2013) philosophy of performance measurement helps public managers name, observe, and at times count the value they produce, whether in education, public health, safety, crime prevention, housing, or other areas. Moore's (2013) version of Public Value Accounting (PVA) is an alternative that outlines the values for citizens to identify what is produced by, and reflected in, agency operations. Furthermore, Moore (2013) offers a Public Value 
Scorecard to help public managers focus on the actions necessary to build legitimacy and support for the envisioned value, and on the innovations that have to be made in existing operational capacity.

According to Bozeman (2007, 13), "public values are those providing normative consensus about (1) the rights, benefits, and prerogatives to which citizens should (and should not) be entitled; (2) the obligations of citizens to society, the state, and one another; (3) and the principles on which governments and policies should be based." "Public values failure occurs when neither the market nor public sector provides goods and services required to achieve public values" (Bozeman 2007, 144). The likelihood of public values failure increases when "there are insufficient means of ensuring articulation and effective communication of core values, or if processes for aggregating values lead to distortions" (Bozeman 2007, 145). Public value extends beyond narrow monetary outcomes to include benefits that are valued by citizens. A specific framework has been developed for identifying and assessing obtainment of public values, "public value mapping" (Bozeman 2007), which has been applied in a variety of social and policy contexts. The approach offers an assessment tool to determine the nature and extent of public value creation in the area.

Meynhardt (2009; 2015) proposes different public value dimensions that more closely direct both Moore's strategic triangle and Bozeman's ideas about "normative consensus" to the level of actual experience, where values do or do not "exist." In line with Van Dooren, Bouckaert, and Halligan (2015), Meynhardt (2009) views performance in the public sector from a logic of contributing to public value. Public sector performance is about the impact on individual's lives as perceived and evaluated by the public itself. Meynhardt (2009) argues that public value should be grounded in people's perception and sense making ("perception is reality"). This perspective allows for linking a process perspective (Moore 1995) and an institutional perspective (Bozeman 2007) with an outcome perspective in terms of actual needs' fulfillment. According to Meynhardt (2009), public value "is situated in relationships between the individual and 'society,' founded in individuals, constituted by subjective evaluations against basic needs, activated by and realized in emotional-motivational states, and produced and reproduced in experience-intense practices" (Meynhardt 2009, 212). Consequently, Meynhardt (2009) draws upon the psychological concept of basic needs as a frame of reference for public value evaluation.

In translating basic needs' fulfillment, four possible value creation dimensions can be distinguished: (1) an instrumental-utilitarian value; e.g., better service or better financial outcomes; (2) a moral-ethical value; e.g., increased fairness and justice; (3) a political-social value; e.g., improved relations between different groups in society; and (4) a hedonistic-aesthetical value; e.g., better reputation and self-esteem of an administration. From this needs-based framework, Meynhardt (2015) developed a Public Value Scorecard (PVSC), which measures the type and the extent to which public value is created in each dimension. This PVSC epistemology allows individuals, groups, and organizations to rate the intended or realized public value creation of an initiative, product, or service along key dimensions (Meynhardt 
2015). CE should support innovative approaches to enhance either one or a combination of the four dimensions. The following hypothesis is offered:

H6: In the public sector, the degree of CE is positively associated with an increase in public value creation in (a) an instrumental-utilitarian dimension; (b) a moral-ethical dimension; (c) a political-social dimension; and (d) a hedonistic-aesthetical dimension.

\section{DISCUSSION AND CONCLUSION}

While our knowledge of entrepreneurship in general and, more specifically, CE as an identifiable strategy has advanced over the last four decades, much work remains to expand our knowledge of the differences in how CES is manifested within the context of "public sector organizations." This article provides an integrative model of antecedents, components, and outcomes of $\mathrm{CE}$ as an identifiable strategy within the public sector. We focus on CES in the public sector for two reasons. First, the public sector is significant in today's economic climate in providing for the needs of society and economic prosperity. Second, the form of CES in the public sector (due to antecedents, components, and outcomes of $\mathrm{CE}$ with public value as a performance measure to enhance strategic orientation) is significantly different from the form of CES in the private sector that has underpinned the majority of entrepreneurship and CE research. By reconceptualizing CES in the public sector, we hope to propel CES research along an exciting new path.

The primary focus of public sector to serve the diverse needs of society together with the need to remain financially viable leads to a set of antecedents, components, and outcomes that are more complex and multifaceted than those in the private sector. Our understanding of CES in the public sector incorporates (1) the external environmental conditions that generate entrepreneurial activity; (2) entrepreneurial strategic vision, organizational conditions, EO and individual behaviors that reflect the overall level of such processes and behaviors; and (3) public value as an outcome of CES within organizational outcomes resulting from entrepreneurial actions, including the development of venturing and renewal that, in turn, leads to enhanced levels of performance.

CES does not just happen and is not a one-time implementation but rather should be the vision of top management who needs to monitor and evaluate the system in place and ensure it is linked to the achievement of organizational goals and objectives. CES practices would not only allow top management within the public sector to formulate superior strategies, but enable them to identify key business opportunities. A public sector organization's sustained effort in CES depends on individual members continuing to identify opportunities and undertake entrepreneurial activities, and the support and facilitation of such activities by the organization's top management. Effectively, they balance the exploitation of current entrepreneurial opportunities while searching for future entrepreneurial opportunities (Ireland, Covin, and Kuratko 2009). The requirement for public sector entrepreneurial 
approaches becomes more fundamental as public revenues are reduced and public services are questioned.

While exploratory in nature, the development of a model of CES in the public sector comes at a time when the interest in public sector entrepreneurship and economic reform and sustainability from the global challenges of recent years is recognized as fundamental for future value creation. Linkages among behaving entrepreneurially, serving the core recipients of the public sector, satisfying the expectations of a multitude of diverse stakeholders, and achieving the organizational mission and measures of public value performance have either not been established or, if they exist, can be relatively complex. CES within the public sector would identify market opportunities within the political landscape, optimize the performance enhancing potential of entrepreneurship and innovation, and carry stakeholders in a way that both permits risk and recognizes the stewardship of public sector resources. By adapting some of the principles that have been so effective in the private sector, while also recognizing the distinctiveness of the public sector, leaders in the public sector have a similar opportunity to generate reform and change that will lead to economic recovery and growth as well as social cohesion.

\section{CONTRIBUTIONS TO PUBLIC SECTOR CES LITERATURE}

The model makes several contributions to the growing literature on CES. The model brings specificity to the concept of CES in the public sector, a concept that is undefined in the academic literature. Bartlett and Dibben (2002) propose a distinction between two types of entrepreneurial government, namely entrepreneurial behavior focused on public needs (external) and entrepreneurial behavior that focuses on managerial empowerment (internal). By taking external as well as internal factors into account, the proposed model allows for a more comprehensive understanding of CES in the public sector.

Adapting from the CE and strategic management literature, this model builds on existing models and also introduces the concepts of (1) entrepreneurial alertness; (2) entrepreneurial self-efficacy; and (3) entrepreneurial effectuation. The literature on entrepreneurial alertness, entrepreneurial self-efficacy, and entrepreneurial effectuation were combined with the components of CES literature to form the basis for the public sector model. The model suggests viable pathways for CES implementation in the public sector, resulting in greater levels of CE.

Second, the model offers an important contribution to the entrepreneurship and strategic management literatures by bringing specificity to the core components of CES within the public sector and the role of external antecedents and internal CES components in facilitating multidimensional performance outcomes. Similar to the identification of specific components of CES strategy in the private sector by Ireland, Covin, and Kuratko (2009) and Kreiser et al. (2011), this model adds substance to the concept and facilitates understanding of CES in the public sector.

Third, CES in the private sector is difficult to create, and even more difficult to perpetuate (Ireland, Covin, and Kuratko 2009). In the context of the public sector, 
this is even more challenging due to the bureaucratic nature of public sector organizations that are subject to public scrutiny and transparency requirements. Certain external environment conditions, combined with top management drive to release creative energy in pursuit of the public interest, may initiate the exploration and implementation of a CES in the public sector. As in the private sector, for this to work effectively, it requires a commitment from individuals throughout the organization. All four components of the CES must be aligned with external environment conditions in order to strengthen the level of congruence among the core components of CES in the public sector. Further congruence is necessary between the internal CES components in order to facilitate higher levels of CE and, in turn, desirable outcomes in terms of public value performance. The components of CES need to be aligned with the organization's environment, but also with its unique set of resources.

Fourth, the proposed model constitutes the first attempt to systematically link the public sector CES literature (e.g., Kearney, Hisrich, and Roche 2007; 2008; 2010) to a performance measure that is not generic but fits the public sector's purpose of serving society: public value (e.g., Moore 1995; 2013; Meynhardt 2009; Meynhardt and Bartholomes 2011). Previous theorizing has emphasized that entrepreneurship in the public sector is not and should not be targeted solely at financial gains (e.g., Denhardt and Denhardt 2010; Sadler 2000), but has not offered an alternative indicator for measuring performance. Enhancing a model of public sector CES with a holistic understanding of public organizations' value creation can help carve out differences between sectors and derive testable propositions to explain variance in public value creation. We believe that looking at CES from a public value perspective infuses a specific notion of entrepreneurship that is commensurate to the nature of work in the public sector and naturally contextualizes it. Hence, it deliberately introduces the idea of involving citizens as co-producers of public value.

\section{IMPLICATIONS FOR SCHOLARS: PRACTICE AND FUTURE RESEARCH}

For decades, researchers and policymakers have investigated the significant role entrepreneurship plays in job creation, new business ventures, and the commercialization of new technologies that promote economic growth and development. With the success of entrepreneurship in transforming economies, industries, and societies, little attention has been given to understand its role in transforming public sector. Similar to Ireland, Covin, and Kuratko (2009) and Kreiser et al. (2011), this model implies that all the components of CES must be aligned in order to achieve desirable outcomes. Failure to align any of the core components will have negative implications for CES success within the public sector. Recognizing variance in public value creation across different levels and areas of the public sector helps explain more realistically how CES can be manifested within public sector organizations. In addition, it recognizes the system that needs to be implemented to support congruence among the CES components throughout the public sector. In addition to the 
theoretical implications, this research also has practical implications for top management of public sector organizations. Public sector managers face a number of important decisions about CES with regard to funding, resources, public scrutiny, and economic conditions. Further, they are also responsible to a more diverse group of stakeholders. It is the responsibility of top management to ensure that all resources are managed efficiently and effectively in favor of a CES that benefits a diverse group of stakeholders and the wider community to whom public sector organizations are responsible.

For researchers, there are numerous avenues that merit exploration. Building on the theoretical propositions and the model of CES in the public sector outlined in this article requires research to gain a more comprehensive understanding of the relationships posed and differentiate among diverse public sector entities. Empirical research is needed to explicate and understand how to develop congruence between the external and internal environment in order to achieve successful outcomes through the utilization of CES within the different public sector entities; for example, government entities and non-profit entities. How can CES within the public sector enhance alertness to and identify entrepreneurial opportunities that lead to desirable outcomes? Under which environmental conditions can public administrations create the most public value and which internal factors mediate or moderate this relationship? Is entrepreneurship in regulation, procurement, social services, or incarceration the same, or not? In the public sector, does the nature of the task or issue to be dealt with affect the applicability framework? If not, why does the task or issue not matter?

CES in the public sector raises the possibility of highly favorable outcomes for organizations, stakeholders, and the wider community. By adapting some of the entrepreneurial principles and strategies that have been so effective in the private sector, top management of the public sector have a similar opportunity to transform the public sector through CES and thereby to contribute to a functioning society.

\section{REFERENCES}

Agarwal, R. and C. E. Helfat. 2009. "Strategic Renewal of Organizations." Organization Science 20(2): 281-293.

Aldrich, H. E. 1979. Organizations and Environments. Englewood Cliffs, NJ: Prentice-Hall.

Andrews, R., G. A. Boyne, J. Law, and R. M. Walker. "External Constraints and Public Sector Performance: The Case of Comprehensive Performance Assessment in English Local Government." Public Administration 83(4): 639-656.

Andrews, R., G. A. Boyne, J. Law, and R. M. Walker. 2007. "Centralization, Organizational Strategy, and Public Service Performance." Journal of Public Administration Research and Theory 19: 57-80.

Andrews, R., G. A. Boyne, J. Law, and R. M. Walker. 2009. "Strategy, Structure and Process in the Public Sector: A Test of the Miles and Snow Model." Public Administration 87(4): 732-749.

Andrews, R., G. A. Boyne, K. J. Meier, L. J. O’Toole, Jr., and R. M. Walker. 2011. "Vertical Strategic Alignment and Public Service Performance.” Public Administration 90(1): 77-98. 
Antoncic, B. and R. D. Hisrich. 2001. "Intrapreneurship: Construct Refinement and Cross-Cultural Validation." Journal of Business Venturing 16: 495-527.

Ardichvili, A., R. Cardozo, and S. Ray. 2003. "A Theory of Entrepreneurial Opportunity Identification and Development." Journal of Business Venturing 18(1): 105-123.

Austin, J., H. Stevenson, and J. Wei-Skillern. 2006. "Social and Commercial Entrepreneurship: Same, Different or Both?" Entrepreneurship Theory and Practice 30(1): 1-22.

Bandura, A. 1977a. "Self-Efficacy: Toward a Unifying Theory of Behavioral Change." Psychological Review 84(2): 191-215.

Bandura, A. 1977b. Social Learning Theory. Englewood Cliffs, NJ: Prentice Hall.

Bandura, A. 1997. Self-Efficacy: The Exorcize of Control. New York: W. H. Freeman.

Baron, R. A. and J. Tang. 2011. "The Role of Entrepreneurs in Firm-Level Innovation: Joint Effects of Positive Affect, Creativity, and Environmental Dynamism.” Journal of Business Venturing 26: 49-60.

Bartlett, C. A. and S. Ghoshal. 1997. "The Myth of the General Manager: New Personal Competencies for New Management Roles." California Management Review 40(1): 92-116.

Bartlett, D. and P. Dibben. 2002. "Public Sector Innovation and Entrepreneurship: Case Studies from Local Government." Local Government Studies 8(4): 107-121.

Battilana, J. 2006. "Agency and Institutions: The Enabling Role of Individuals' Social Position." Organization 13: 653-676.

Baum, J. R., E. A. Locke, and K. G. Smith. 2001. "A Multidimensional Model of Venture Growth." Academy of Management Journal 44: 292-304.

Bellone, C. and G. Goerl. 1992. "Reconciling Public Sector Entrepreneurship and Democracy." Public Administration Review 52(2): 130-134.

Benington, J. and M. Moore. 2011. "Public Value in Complex and Changing Times." Pp. 1-30 in J. Benington and M. Moore, eds., Public Value: Theory and Practice. Basingstoke: Palgrave Macmillan.

Block, Z. and O. A. Ornati. 1987. "Compensating Corporate Venture Managers." Journal of Business Venturing 2(1): 41-51.

Borins, S. 1998. Innovating with Integrity: How Local Heroes are Transforming American Government. Washington, DC: Georgetown University Press.

Borins, S. 2000. "Loose Cannons and Rule Breakers, or Enter-Prising Leaders? Some Evidence about Innovative Public Managers." Public Administration Review 60(6): 498-507.

Borins, S. 2014. The Persistence of Innovation in Government. Washington, DC: Brookings Institution Press with Ash Center for Democratic Governance and Innovation.

Boris, E. T. and C. E. Steuerle. 2006. "Scope and Dimensions of the Non-Profit Sector." Pp. 66-88 in W. W. Powell and R. Sternberg, eds., The Non-Profit Sector: A Research Handbook. New Haven, CT: Yale University Press.

Boyd, N. G. and G. S. Vozikis. 1994. "The Influence of Self-Efficacy on the Development of Entrepreneurial Intentions and Actions." Entrepreneurship Theory and Practice 18: 63-90.

Boyett, I. 1997. "The Public Sector Entrepreneur: A Definition.” International Journal of Entrepreneurial Behaviour and Research 3(2): 77-92.

Boyne, G. and J. Gould-Williams. 2003. "Planning Performance in Public Organizations: An Empirical Analysis." Public Management Review 5(1): 115-132.

Boyne, G. A. 2006. "Strategies for Public Service Turnaround: Lessons from the Private Sector?" Administration and Society 38(3): 365-388.

Bozeman, B. 2007. Public Values and Public Interest: Counterbalancing Economic Individualism. Washington, DC: Georgetown University Press. 
Bozeman, B. and G. Kingsley. 1998. "Risk Culture in Public and Private Organizations." Public Administration Review 58(2): 109-118.

Brown, L. and S. P. Osborne. 2013. "Risk and Innovation: Towards a Framework or Risk Governance in Public Services." Public Management Review 15(2): 186-208.

Bruno, A. V. and T. T. Tyebjee. 1982. "The Environment for Entrepreneurship.” Pp. 288-307 in C. Kent, D. Sexton and K. Vesper, eds., The Encyclopaedia of Entrepreneurship. Englewood Cliffs, NJ: Prentice-Hall.

Bruton, G. D., D. Ahlstrom, and H.-L. Li. 2010. "Institutional Theory and Entrepreneurship: Where are We Now and Where Do We Need to Move in the Future?" Entrepreneurship Theory and Practice 34: 421-40.

Bryson, J. M. 2010. "The Future of Public and Nonprofit Strategic Planning in the United States." Public Administration Review 70(1): 255-267.

Bryson, J. M. 2011. Strategic Planning for Public and Nonprofit Organizations: A Guide to Strengthening and Sustaining Organizational Achievement, Vol. 1. San Francisco, CA: John Wiley \& Sons.

Bryson, J. M., B. C. Crosby, and L. Bloomberg. 2014. "Public Value Governance: Moving beyond Traditional Public Administration and the New Public Management." Public Administration Review 74 (4): 445-456.

Bryson, J. M., B. C. Crosby, and L. Bloomberg, eds. 2015. Public Value and Public Administration. Washington, DC: Georgetown University Press.

Burgelman, R. A. 1983. "Corporate Entrepreneurship and Strategic Management: Insights From a Process Study." Management Science 29(12): 1349-1363.

Caruana, A., M. T. Ewing, and B. Ramaseshan. 2002. "Effects of Some Environmental Challenges and Centralization on the Entrepreneurial Orientation and Performance of Public Sector Entities." Service Industries Journal 22(2): 43-58.

Covin, J. G. and D. P. Slevin. 1989. "Strategic Management of Small Firms in Hostile and Benign Environments." Strategic Management Journal 1(10): 75-87.

Covin, J. G. and D. P. Slevin. 1991. "A Conceptual Model of Entrepreneurship as Firm Behavior." Entrepreneurship Theory and Practice 16(1): 7-25.

Crewson, P. E. 1997. "Public-Service Motivation: Building Empirical Evidence of Incidence and Effect." Journal of Public Administration Research and Theory 4: 499-518.

Currie, G., M. Humphreys, D. Ucbasaran, and S. Mcmanus. 2008. "Entrepreneurial Leadership in the English Public Sector: Paradox or Possibility?" Public Administration 86(4): 987-1008.

Currie, G. and S. J. Proctor. 2005. "The Antecedents of Middle Manager's Strategic Contribution: The Case of a Professional Bureaucracy." Journal of Management Studies 42: $1325-1356$.

Damanpour, F. and M. Schneider. 2009. "Characteristics of Innovation and Innovation Adoption in Public Organizations: Assessing the Role of Managers." Journal of Public Administration Research and Theory 19(3): 495-522.

Damanpour, F., R. M. Walker, and C. N. Avellaneda. 2009. "Combinative Effects of Innovation Types and Organizational Performance: A Longitudinal Study of Service Organizations." Journal of Management Studies 46(4): 650-675.

Davidson, O. B. and D. Eden. 2000. "Remedial Self-Fulfilling Prophecy: Two Field Experiments to Prevent Golem Effects Among Disadvantaged Women." Journal of Applied Psychology 85(3): 386-398.

Denhardt, R. B. and J. V. Denhardt. 2000. "The New Public Service: Serving Rather than Steering.” Public Administration Review 60(6): 549-559. 
Dess, G. G. and D. W. Beard. 1984. "Dimensions of Organizational Task Environments." Administrative Science Quarterly 30: 52-73.

Dilulio, J. J., G. Garvey, and D. Kettl. 1993. Improving Government Performance: An Owner's Manual. Washington, DC: Brookings Institution.

DiMaggio, P. 1988. "Interest and Agency in Institutional Theory.” Pp. 3-22 in L. Zucker, ed., Institutional Patterns and Organizations. Cambridge, MA: Ballinger.

Doig, J. W. and E. C. Hargrove. 1990. Leadership and Innovation: Entrepreneurs in Government. Baltimore, MD: Johns Hopkins University Press.

Ericsson, K. A. 2006. "Protocol Analysis and Expert Thought: Concurrent Verbalizations of Thinking During Experts' Performance on Representative Tasks.” Pp. 223-242 in K. A. Ericsson, N. Charness, P. J. Feltovich, and R. R. Hoffman, eds., The Cambridge Handbook of Expertise and Expert Performance. Cambridge: Cambridge University Press.

Floyd, S. W. and B. Wooldridge. 1997. "Middle Management's Strategic Influence and Organizational Performance." Journal of Management Studies 34: 465-85.

Forster, J., P. Graham, and J. Wanna. 1996. "The New Public Entrepreneurialism.” Pp. 1-14 in J. Wanna, J. Foster, and P. Graham, eds., Entrepreneurial Management in the Public Sector. Melbourne: Macmillan.

Frayne, C. A. and G. P. Latham. 1987. "Application of Social Learning Theory to Employee Self-Management of Attendance." Journal of Applied Psychology 72(3): 387-92.

Gaglio, C. M. and R. P. Taub. 1992. "Entrepreneurs and Opportunity Recognition." Pp. 136-147 in N. C. Churchill, S. Birley, W. Bygrave, D. Muzyka, and W. E. Wetzel, eds., Frontiers of Entrepreneurship Research. Wellesley, MA: Babson College.

Goodale, J. C., D. F. Kuratko, J. S. Hornsby, and J. G. Covin. 2011. "Operations Management and Corporate Entrepreneurship: The Moderating Effect of Operations Control on the Antecedents of Corporate Entrepreneurial Activity in Relation to Innovation Performance." Journal of Operations Management 29(1-2): 116-127.

Granovetter, M. 1985. "Economic Action and Social Structure: The Problem of Embeddedness." American Journal of Sociology 481-510.

Guth, W. D. and A. Ginsberg. 1990. "Corporate Entrepreneurship.” Strategic Management Journal (special issue) 11: 5-15.

Hartley, J., E. Sørensen, and J. Torfing. 2013. "Collaborative Innovation: A Viable Alternative to Market Competition and Organizational Entrepreneurship." Public Administration Review 73(6): 821-830.

Heller, T. 1999. "Loosely Coupled Systems for Corporate Entrepreneurship: Imagining and Managing the Innovation Project/Host Organization Interface." Entrepreneurship Theory and Practice 24(2): 25-31.

Hendrick, R. 2003. "Strategic Planning Environment, Process, and Performance in Public Agencies: A Comparative Study of Departments in Milwaukee." Journal of Public Administration Research and Theory 13: 491-519.

Hisrich, R. D. 1990. “Entrepreneurship/Intrapreneurship.” American Psychologist 45(2): 209-222.

Hisrich, R. D. and C. Kearney. 2011. Corporate Entrepreneurship: How to Create a Thriving Entrepreneurial Spirit throughout Your Company. New York: McGraw-Hill.

Hisrich, R. D. and M. P. Peters. 1986. "Establishing a New Business Venture within a Firm." Journal of Business Venturing 1: 30-332.

Holt, D. T., M. W. Rutherford, and G. R. Clohessy. 2007. "Corporate Entrepreneurship: An Empirical Look at Individual Characteristics, Context, and Process." Journal of Leadership and Organizational Studies 13(4): 40-54. 
Hornsby, J. S., D. T. Holt, and D. F. Kuratko. 2008. "The Dynamic Nature of Corporate Entrepreneurship: Assessing the CEAI." Best Paper Proceedings: National Academy of Management (CD Rom), Ancheim, CA, August 8-13.

Hornsby, J. S., D. F. Kuratko, D. A. Shepherd, and J. P. Bott. 2009. "Managers' Corporate Entrepreneurial Actions: Examining Perception and Position." Journal of Business Venturing 24(3): 236-247.

Hornsby, J. S., D. F. Kuratko, and S. Zahra. 2002. "Middle Managers' Perception of the Internal Environment for Corporate Entrepreneurship: Assessing a Measurement Scale." Journal of Business Venturing 17(3): 253-273.

Ireland, D. R., J. G. Covin, and D. F. Kuratko. 2009. "Conceptualizing Corporate Entrepreneurship Strategy." Entrepreneurship Theory and Practice 33(1): 19-46.

Ireland, R. D., D. F. Kuratko, and M. H. Morris. 2006a. "A Health Audit for Corporate Entrepreneurship: Innovation at all Levels: Part I." Journal of Business Strategy 27(1): $10-17$.

Ireland, R. D., D. F. Kuratko, and M. H. Morris. 2006b. "A Health Audit for Corporate Entrepreneurship: Innovation at All Levels: Part II." Journal of Business Strategy 27(2): 21-30.

Jennings, D. F. and D. M. Young. 1990. "An Empirical Comparison between Objective and Subjective Measures of the Product Innovation Domain of Corporate Entrepreneurship." Entrepreneurship Theory and Practice 15(1): 53-66.

Kearney, C., R. D. Hisrich, and F. W. Roche. 2007. "Facilitating Public Sector Corporate Entrepreneurship Process: A Conceptual Model." Journal of Enterprising Culture 15(3): 275-299.

Kearney, C., R. D. Hisrich, and F. W. Roche. 2008. "A Conceptual Model of Public Sector Corporate Entrepreneurship.” International Entrepreneurship Management Journal 4(3): 295-313.

Kearney, C., R. D. Hisrich, and F. W. Roche. 2009. "Public and Private Sector Entrepreneurship: Similarities, Differences or a Combination?" Journal of Small Business and Enterprise Development 16(1): 26-46.

Kearney, C., R. D. Hisrich, and F. W. Roche. 2010. "Change Management through Entrepreneurship in Public Sector Enterprises." Journal of Developmental Entrepreneurship 15(4): $1-23$.

Kearney, C. and M. H. Morris. 2015. "Strategic Renewal as a Mediator of Environmental Effects on Public Sector Performance." Small Business Economics 45: 425-445.

Khandwalla, P. N. 1977. The Design of Organizations. New York: Harcourt Bruce Jovanovich.

Khandwalla, P. N. 1987. "Generators of Pioneering-Innovative Management: Some Indian Evidence.” Organizational Studies 8(1): 39-59.

Kingdon, J. 1984. Agendas, Alternatives and Public Policies. Boston: Little, Brown and Company.

Kirzner, I. M. 1973. Competition and Entrepreneurship. Chicago: University of Chicago Press.

Kirzner, I. M. 1997. "Entrepreneurial Discovery and the Competitive Market Process: An Austrian Approach." Journal of Economic Literature 35: 60-85.

Klein, P. G., J. T. Mahoney, A. M. McGahan, and C. N. Pitelis. 2010. "Toward a Theory of Public Entrepreneurship.” European Management Review 7: 1-15.

Kreiser, P. M., D. F. Kuratko, J. G. Covin, and J. M. House. 2011. "Operationalizing Corporate Entrepreneurship Strategy (CES): A Configurational Approach.” Presented at the Academy of Management Meetings, San Antonio, TX, August 12-16.

Krueger, N. and P. R. Dickson. 1994. "How Believing in Ourselves Increases Risk Taking: Perceived Self-Efficacy and Opportunity Recognition.” Decision Sciences 25(3): 385-400. 
Kuratko, D., R. Montagno, and J. Hornsby. 1990. "Developing an Intrapreneurial Assessment Instrument for Effective Corporate Entrepreneurial Environment." Strategic Management Journal II (Summer): 49-58.

Kuratko, D. F., J. S. Hornsby, and M. G. Goldsby. 2004. "Sustaining Corporate Entrepreneurship: A Proposed Model of Perceived Implementation/Outcome Comparisons at the Organizational and Individual Levels." International Journal of Entrepreneurship and Innovation 5(2): 77-89.

Kuratko, D. F., J. S. Hornsby, and J. W. Bishop. 2005. “An Examination of Managers' Entrepreneurial Actions and Job Satisfaction." International Entrepreneurship and Management Journal 1(3): 275-291.

Kuratko, D. F., R. D. Ireland, and J. S. Hornsby. 2001. "The Power of Entrepreneurial Actions: Insights from Acordia, Inc.” Academy of Management Executive 16(4): 1-12.

Latham, G. P. and C. A. Frayne. 1989. "Self-Management Training for Increasing Job Attendance: A Follow-Up and a Replication." Journal of Applied Psychology 74(3): 411-16.

Linden, R. 1990. From Vision to Reality: Strategies of Successful Innovators in Government. Charlottesvile, SC: LEL Enterprises.

Llewellyn, S. and E. Tappin. 2003. "Strategy in the Public Sector: Management in the Wilderness." Journal of Management Studies 40(4): 955-982.

Lumpkin, G. T. and G. Dess. 1996. "Clarifying the Entrepreneurial Orientation Construct and Linking it to Performance." Academy of Management Review 21(2): 135-172.

Mack, W. R., D. Green, and A. Vedlitz. 2008. "Innovation and Implementation in the Public Sector: An Examination of Public Entrepreneurship." Review of Policy Research 25(3): 233-252.

Meier, K. J. and L. J. O'Toole,Jr. 2009. “The Dogs that Didn’t Bark: How Public Managers Handle Environmental Shocks." Public Administration 87(3): 485-502.

Meynhardt, T. 2009. "Public Value Inside: What is Public Value Creation?" International Journal of Public Administration 32(3): 192-219.

Meynhardt, T. and S. Bartholomes. 2011. "(De)Composing Public Value: In Search of Basic Dimensions and Common Ground." International Public Management Journal 14(3): 284-308.

Meynhardt, T. and F. E. Diefenbach. 2012. "What Drives Entrepreneurial Orientation in the Public Sector? Evidence from Germany's Federal Labor Agency." Journal of Public Administration Research and Theory 22(4): 761-792.

Meynhardt, T. 2015. "Public Value: Turning a Conceptual Framework into a Scorecard." Pp. 147-169 in J. M. Bryson, B. C. Crosby, and L. Bloomberg, eds., Public Value and Public Administration. Washington, DC: Georgetown University Press.

Meynhardt, T. and J. Metelmann. 2009. "Pushing the Envelope: Creating Public Value in the Labor Market: An Empirical Study on the Role of Middle Managers." International Journal of Public Administration 32(3-4): 273-311.

Miles, R. E. and C. C. Snow. 1978. Organizational Strategy, Structure and Process. New York: McGraw-Hill.

Miller, D. 1983. "The Correlates of Entrepreneurship in Three Types of Firms." Management Science 27: 770-791.

Miller, D., M. J. Fern, and L. B. Cardinal. 2007. "The Use of Knowledge for Technological Innovation within Diversified Firms." Academy of Management Journal 50(2): 307-326.

Miller, K. D. 2007. "Risk and Rationality in Entrepreneurial Processes." Strategic Entrepreneurship Journal 1: 57-74.

Miner, J. B. 1997. A Psychological Typology of Successful Entrepreneurs. Westport, CT: Quorum Books. 
Mitchell, R. K., L. W. Busenitz, B. Bird, C. M. Gaglio, J. S. McMullen, E. A. Morse, and J. B. Smith. 2007. "The Central Question in Entrepreneurial Cognition Research." Entrepreneurship Theory and Practice 31(1): 1-27.

Moon, M. J. 1999. "The Pursuit of Managerial Entrepreneurship: Does Organization Matter?" Public Administration Review 59(1): 31-43.

Moore, M. H. 1995. Creating Public Value: Strategic Management in Government. Cambridge, MA: Harvard University Press.

Moore, M. H. 2013. Recognizing Public Value. Cambridge, MA: Harvard University Press.

Moore, M. H. and J. Hartley. 2008. "Innovations in Governance." Public Management Review 10(1): 3-20.

Morris, M. H. and F. F. Jones. 1999. "Entrepreneurship in Established Organizations: The Case of the Public Sector." Entrepreneurship Theory and Practice 24(1): 71-91.

Morris, M. H., D. F. Kuratko, and J. G. Covin. 2011. Corporate Entrepreneurship and Innovation, 3rd ed. Mason, OH: Thomson/South-Western.

Morris, M. H., J. W. Webb, and R. J. Franklin. 2011. "Understanding the Manifestation of Entrepreneurial Orientation in the Nonprofit Context." Entrepreneurship Theory and Practice 35(5): 947-971.

Nutt, P. C. 2005. “Comparing Public and Private Sector Decision-Making Practices.” Journal of Public Administration Research and Theory 30: 1-30.

Nutt, P. C. and R. W. Backoff. 1992. Strategic Management of Public and Third Sector Organizations. San Francisco: Jossey-Bass Inc.

Nutt, P. C. and R. W. Backoff. 1993. "Transforming Public Organizations with Strategic Management and Strategic Leadership." Journal of Management 19(2): 299-347.

Nutt, P. C. and R. W. Backoff. 1995. "Strategy for Public and Third-Sector Organizations." Journal of Public Administration Research and Theory 5(2): 189-211.

Osborne, D. and T. A. Gaebler. 1992. Reinventing Government: How the Entrepreneurial Spirit is Transforming the Public Sector. Boston, MA: Addison-Wesley.

Osborne, S. P. and L. Brown. 2011. "Innovation, Public Policy and Public Services in the UK: The World that would be King?" Public Administration 89(4): 1335-1350.

Pfeffer, J. 1994. Competitive Advantage through People. Boston: Harvard Business School Press.

Ramamurti, R. 1986. "Public Entrepreneurs: Who They Are and How They Operate." California Management Review 28(3): 142-158.

Ray, S. and R. Cardozo. 1996. "Sensitivity and Creativity in Entrepreneurial Opportunity Recognition: A Framework for Empirical Investigation." Presented at the Sixth Global Entrepreneurship Research Conference, Imperial College, London, UK, August 29-30.

Rutherford, M. W. and D. T. Holt. 2007. "Corporate Entrepreneurship: An Empirical Look at the Innovativeness Dimension and its Antecedents." Journal of Organizational Change Management 20(3): 429-446.

Sadler, R. J. 2000. "Corporate Entrepreneurship in the Public Sector: The Dance of the Chameleon." Australian Journal of Public Administration 59(2): 25-43.

Salamon, L. M. 1992. America's Non-Profit Sector: A Primer. New York: The Foundation Center.

Sanger, M. B. and M. A. Levin. 1992. "Using Old Stuff in New Ways: Innovation as a Case of Evolutionary Tinkering." Journal of Policy Analysis and Management 11(1): 88-115.

Sarasvathy, S. D. 2001. "Causation and Effectuation: Toward a Theoretical Shift from Economic Inevitability to Entrepreneurial Contingency." Academy of Management Review 26(2): 243-288.

Sathe, V. 1989. "Fostering Entrepreneurship in Large Diversified Firm." Organizational Dynamics 18(1): 20-32. 
Scherer, R. F., J. S. Adams, S. S. Carley, and F. A. Wiebe. 1989. "Role Model Performance Effects on Development of Entrepreneurial Career Preference." Entrepreneurship Theory and Practice 13: 53-71.

Shepherd, D. A., J. S. McMullen, and P. D. Jennings. 2007. "The Formation of Opportunity Beliefs: Overcoming Ignorance and Doubt." Strategic Entrepreneurship Journal 1(1): 75-95.

Shockley, G. E., P. M. Frank, and R. R. Stough. 2002. "Toward a Theory of Public Sector Entrepreneurship." Paper presented NCIIA Seventh Annual Meeting: Big Ideas in a Small World, Boston, March 20-22.

Simsek, Z., J. F. Veiga, and M. H. Lubatkin. 2007. "The Impact of Managerial Environmental Perceptions on Corporate Entrepreneurship: Towards Understanding Discretionary Slack's Pivotal Role." Journal of Management Studies 44(8): 1398-1424.

Slevin, D. P. and J. G. Covin. 1997. "Strategy Formation Patterns, Performance, and the Significance of Context." Journal of Management 23(2): 189-209.

Spano, A. 2009. "Public Value Creation and Management Control Systems." International Journal of Public Administration 32(3-4): 328-348.

Stajkovic, A. D. and F. Luthans. 1998. "Self-Efficacy and Work-Related Performance: A Meta-Analysis." Psychological Bulletin 124(2): 240-61.

Stoker, G. 2006. "Public Value Management: A New Narrative for Networked Governance?" The American Review of Public Administration 36: 41-57.

Stopford, J. M. and C. W. F. Baden-Fuller. 1994. "Creating Corporate Entrepreneurship." Strategic Management Journal 15(7): 521-536.

Sykes, H. B. 1986. "The Anatomy of a Corporate Venturing Program." Journal of Business Venturing 1(3): 275-293.

Talbot, C. 2010. Theories of Performance: Organizational and Service Improvement in the Public Domain. New York: Oxford University Press.

Thompson, J. and B. Doherty. 2006. "The Diverse World of Social Enterprise: A Collection of Social Enterprise Stories.” International Journal of Social Economics 33(5/6): 399-410.

Van Dooren, W., G. Bouckaert, and J. Halligan. 2015. Performance Management in the Public Sector. London: Routledge.

Verbeke, A., J. J. Chrisman, and W. Yuan. 2007. "A Note on Strategic Renewal and Corporate Venturing in the Subsidiaries of Multinational Enterprises." Entrepreneurship, Theory and Practice 31(4): 585-600.

Vigoda, E. 2002. "Administrative Agents of Democracy? A Structural Equation Modelling of the Relationship between Public-Sector Performance and Citizenship Involvement." Journal of Public Administration Research and Theory 12(2): 241-72.

Walker, R. M. 2008. "An Empirical Evaluation of Innovation Types and Organizational Types and Organizational Characteristics: Towards a Configuration Framework." Journal of Public Administration Research and Theory 18: 591-615.

Walker, R. M. 2014. "Internal and External Antecedents of Process Innovation: A Review and Extension." Public Management Review 16(1): 21-44.

Walker, R. M., F. Damanpour, and C. A. Devece. 2011. "Management Innovation and Organizational Performance: The Mediating Effect of Performance Management." Journal of Public Administration Research and Theory 21: 367-386.

Wang, C. L. 2008. "Entrepreneurial Orientation, Learning Orientation, and Firm Performance." Entrepreneurship, Theory and Practice: 635-657.

Weibel, A., K. Rost, and M. Osterloh. 2010. "Pay for Performance in the Public Sector: Benefits and (Hidden) Costs." Journal of Public Administration Research and Theory 20(2): $387-412$. 
Westrup, U. 2012. "Internal Entrepreneurship in the Public Sector: The Challenges of Integrating Innovative Projects into the Regular Organization." Scandinavian Journal of Public Administration 16(4): 97-112.

Wiklund, J. and D. Shepherd. 2003. "Knowledge-Based Resources, Entrepreneurial Orientation, and Performance of Small and Medium-Sized Firms." Strategic Management Journal 24: 1307-1314.

Wright, B. E. 2004. "The Role of Work Context in Work Motivation: A Public Sector Application of Goal and Social Cognitive Theories." Journal of Public Administration Research and Theory 14(1): 59-78.

Wright, B. E. 2007. "Public Service and Motivation: Does Mission Matter?" Public Administration Review 67(1): 54-64.

Zahra S. A. 1996. "Governance, Ownership, and Corporate Entrepreneurship: The Moderating Impact of Industry Technological Opportunities." Academy of Management Journal 39(6): 1713-1735.

Zahra, S. A. 1991. "Predictors and Financial Outcomes of Corporate Entrepreneurship: An Exploratory Study." Journal of Business Venturing 6(4): 259-285.

Zahra, S. A. 1993a. "Environment, Corporate Entrepreneurship, and Financial Performance: A Taxonomic Approach.” Journal of Business Venturing 8(4): 319-340.

Zahra, S. A. 1993b. "A Conceptual Model of Entrepreneurship as Firm Behavior: A Critique and Extension." Entrepreneurship Theory and Practice 14(4): 5-21.

Zahra, S. A. and J. G. Covin. 1995. "Contextual Influences on the Corporate Entrepreneurship Performance Relationship: A Longitudinal Analysis." Journal of Business Venturing 10(1): 43-58.

\section{ABOUT THE AUTHORS}

Dr. Claudine Kearney (claudine.kearney@ucd.ie) is a lecturer at the UCD Quinn School of Business and UCD School of Biomolecular and Biomedical Science. Claudine's research interests focus on corporate entrepreneurship, entrepreneurial orientation and the emergence of entrepreneurial ventures. Claudine has published in leading international journals, as well as books and book chapters, and has presented numerous papers at major international conferences.

Dr. Timo Meynhardt (timo.meynhardt@hhl.de) is Professor of Business Psychology and Leadership at HHL Leipzig Graduate School of Management, Germany, and at the University of St. Gallen, Switzerland. His fields of research include public value management and competency management. 